\title{
AN INDUCED-FLOW KIDNEY-BREAST CANCER IN VITRO MODEL FOR STUDY OF CANCER SUPPRESSION BY VITAMIN D 3 DERIVATIVES
}

\author{
Seungbeom Noh ${ }^{l}$, Po Ki Yuen ${ }^{2}$, Vasiliy N. Goral ${ }^{2}$ and Hanseup Kim ${ }^{l}$ \\ ${ }^{1}$ Electrical and Computer Engineering, University of Utah, Salt Lake City, UT, USA \\ ${ }^{2}$ Science and Technology, Corning Incorporated, Corning, NY, USA
}

\begin{abstract}
This paper reports an in vitro platform that demonstrates the suppression of cancer cells by vitamin $\mathrm{D}_{3}$ derivatives on a single system, by simultaneously enabling (1) co-culture of multiple cells; (2) induced fluidic flows among cells; and (3) cancer suppression by the vitamin $\mathrm{D}_{3}$ derivatives. This in vitro model mainly consists of three wells, each containing kidney cells, breast cancer cells, and final transferred media. The wells are connected by porous membranes that allow fluidic flows by hydrostatic pressure. The developed model successfully (1) co-cultured kidney cells (HKC8) and breast cancer cells (MCF7) to the confluency of $>1,800$ cells $/ \mathrm{mm}^{2}$ under the same media; and (2) showed the suppression of cancer cells by the vitamin $\mathrm{D}_{3}$ derivatives: 25 hydroxyvitmain $\mathrm{D}_{3}\left(25(\mathrm{OH}) \mathrm{D}_{3}\right)$ and 1,25-dihydroxyvitamin $\mathrm{D}_{3}$ $\left(1,25(\mathrm{OH})_{2} \mathrm{D}_{3}\right)$; and (3) demonstrated fluidic flow effects on cancer suppression.
\end{abstract}

\section{INTRODUCTION}

Breast cancer has been one of the top five causes for mortality in the US in recent years [1]. In 2007 it was reported that 125 people in every 100,000 women had breast cancer and 23 people died of the breast cancer [1]. To lower the fatalities, numerous efforts have been reported covering from drug-treatment [2] to X-ray based chemotherapy [1], resulting in notable reduction of fatalities in recent years. However, the treatment processes have been often criticized for accompanied harsh side effects of weight loss, abnormal hormone discretion, and even mental instability [3,4,5].

Breast cancer has recently been proven to be suppressed by the vitamin $\mathrm{D}_{3}$ derivatives, $1,25(\mathrm{OH})_{2} \mathrm{D}_{3}$ [6]. As illustrated in Fig.1, the vitamin $\mathrm{D}_{3}$, gained by food intake or by sun exposure [7], produces subsequent derivatives: first, $25(\mathrm{OH}) \mathrm{D}_{3}$ in the liver and then, $1,25(\mathrm{OH})_{2} \mathrm{D}_{3}$ from the $25(\mathrm{OH}) \mathrm{D}_{3}$ in the kidney [8]. The $1,25(\mathrm{OH})_{2} \mathrm{D}_{3}$, when transferred to the breast cancer cells, suppresses cyclin D-dependent kinases activity and delays G1/S phase of cell cycle, ultimately inhibiting further growth of breast cancer cells [6]. Previous literature reported that the growth of breast cancer cells (MCF7) started to slow down after day 2 of introducing $10^{-7} \mathrm{M}$ of $1,25(\mathrm{OH})_{2} \mathrm{D}_{3}$ in in-vitro 96 wells and at day 7 , approximately $10 \times$ decreased in cell number was observed [6]. However, detailed studies of cancer suppression by vitamin $\mathrm{D}_{3}$, such as translation of individual derivatives among organs and their cross-effects [9], have been much limited mainly due to the lack of low-cost, highthroughput co-culture model. Conventional in vivo models, such as animals, present the issues of cost, throughput, repeatability, controllability as well as ethics, while in vitro 96-well models failed to provide co-culture environments and fluidic flows among cell groups, which is critical to study translational effects that have not been studied yet [10].

To resolve such limitations, we report the development of a low-cost, high-throughput, and co-culture model where the suppression of cancer cells by vitamin $\mathrm{D}_{3}$ derivatives has been demonstrated. Particularly, the fabrication, testing, and measurement results of the developed kidney-breast cancer model are reported.

\section{STRUCTURE AND FABRICATION Structure}

The induced-flow in vitro model consists of three wells, each containing kidney cells, breast cancer cells and final transferred media (Fig. 2), which was described in details in a previous publication [11]. The three wells were fluidically connected through cellulose membranes with either $1.2,5.0$ or $8.0 \mu \mathrm{m}$ pore size, and induced fluidic flow from the first well through the second to the third well by fluidic potential difference. The fluidic potential difference was applied by maintaining the media volumes as $320 \mu 1$, $170 \mu \mathrm{l}$, and $20 \mu \mathrm{l}$ at the kidney, breast cancer, and drain wells, respectively. The media volume was re-adjusted according to the pore size used. The diameter of each well was $6.5 \mathrm{~mm}$ and the height was $10.5 \mathrm{~mm}$. Cellulose membranes provided the fluidic path among wells. The footprint of the membrane was $1 \mathrm{~mm} \times 3.5 \mathrm{~mm}$, while their thicknesses were between 105 and $140 \mu \mathrm{m}$.

\section{Fabrication}

The fabrication of the platform was previously described [11]. Briefly, each set of three holes of a standard flat bottom 96-well holey (bottomless) microplate (Corning Inc., Corning, NY) are linearly connected using two cellulose membranes $(1 \mathrm{~mm} \times 3.5 \mathrm{~mm})$ with either $1.2,5$ or $8 \mu \mathrm{m}$ pore size . A polystyrene film, which was taken from a Corning ${ }^{\circledR}$ HYPERStack ${ }^{\mathrm{TM}}$ Cell Culture Vessel (Corning Inc., Corning, NY) was adhered to the bottom of the standard flat bottom 96-well holey microplate using a double-sided

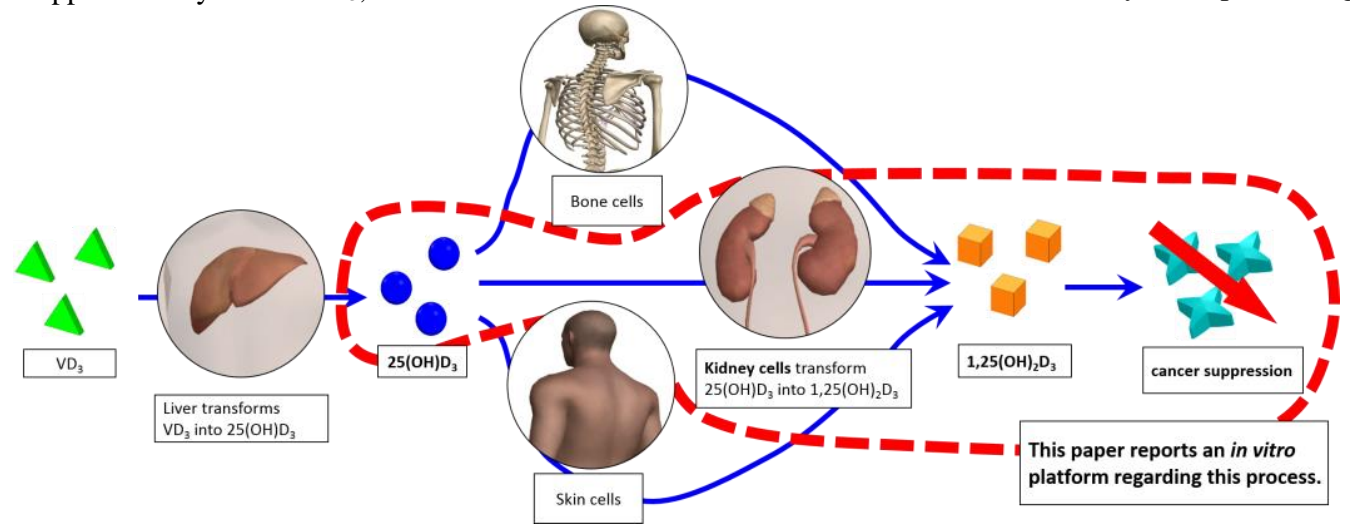

Figure 1. Motivation: Vitamin $D_{3}$ is converted into its subsequent derivatives through different organs, ultimately being capable of suppressing breast cancer cells. 


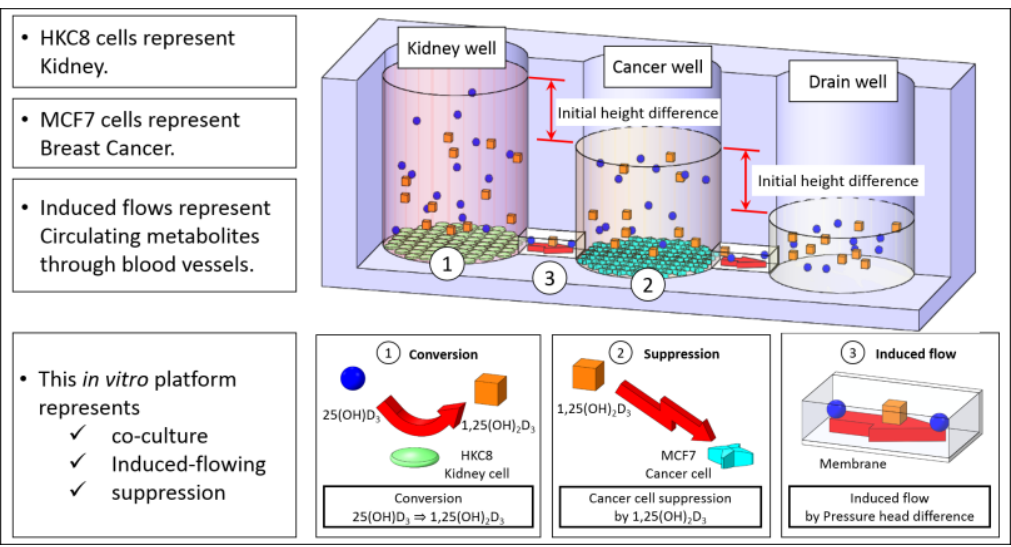

Figure 2. Proposed model that combines multi-cell co-culture, induced-flow, and cancer suppression into a single in vitro platform.

pressure sensitive adhesive sheet $(110 \mathrm{~mm} \times 75 \mathrm{~mm})$ where holes and channels are cut out for the wells and the cellulose membranes, respectively (Fig.2) [11].

\section{Cell culture}

Both HKC8 (ATCC, Manassas, VA) and MCF7 (ATCC, Manassas, VA) cell lines, each representing the kidney and the breast cancers, were cultured in Dulbecco's modified Eagle's medium: Ham's F12 (Cassison Labs, North Logan, UT) supplemented with $10 \%$ fetal bovine serum (Fisher Scientific, Pittsburgh, PA), $1 \%$ amphotericin B (Corning Inc., Manassas, VA) and $1 \%$ penicillin/streptomycin (Lonza, Walkersville, MD). These cell lines were cultured until they reached $80 \%$ confluency in a monolayer in a T75 flask (Corning Inc., Corning, NY). The culture conditions of $37^{\circ} \mathrm{C}$ in a humidified atmosphere containing $5 \% \mathrm{CO}_{2}$ were utilized in the incubator (NU-4750, Nuaire, Plymouth, MN). The media was changed every $3 \sim 4$ days.

Vitamin $\mathrm{D}_{3}$ derivatives, $1,25(\mathrm{OH})_{2} \mathrm{D}_{3}$ and $25(\mathrm{OH}) \mathrm{D}_{3}$, were diluted in pure ethanol into various ranges of concentrations $\left(10^{-}\right.$ $\left.{ }^{5} \sim 10^{-10} \mathrm{M}\right)$ and stored in freezer at $-20^{\circ} \mathrm{C}$. The concentrations of $1,25(\mathrm{OH})_{2} \mathrm{D}_{3}$ and $25(\mathrm{OH}) \mathrm{D}_{3}$ were finally adjusted again in the media right before the use. Note that the concentration of ethanol dilution did not exceed $0.8 \%$ to avoid any toxicity effects on cell growth. The utilized chemical compounds were purchased from EMD Millipore (EMD Chemicals Inc., San Diego, CA).

\section{TESTING METHODOLOGY}

\section{Cell viability measurement}

In order to establish a cell growth reference, the fluorescence intensity of the incubated cells was monitored every 24 hours over 9 days by utilizing a fluorescence spectrometry (Synergy HY, BioTEK Instrument, Winooski, VT). When the HKC8 kidney cells and MCF7 breast cancer cells were cultured to a confluency of $80 \%$, they were harvested by washing twice with PBS and adding $4 \mathrm{ml}$ Trypsin EDTA (Corning Inc,. Manassas, VA). These harvested cells were then seeded in triplicate in the standard 96-well microplate (Corning Inc., Corning, NY). The initial cell numbers ranged between 5,000 and 100,000 cells/well. After 1 day, a cell viability reagent, PrestoBlue (Invitrogen, Frederick, MD), was applied to stain the cells for fluorescence measurement. The mixture ratio was $10 \mu \mathrm{l}$ of PrestoBlue and $90 \mu \mathrm{l}$ of media. After incubation for 30 minutes at $37^{\circ} \mathrm{C}$ and $5 \% \mathrm{CO}_{2}$, the fluorescence intensity of the incubated cells was measured utilizing the light wavelengths at 530 and 590nm.

\section{Cancer suppression measurement}

By 1,25 $(\mathrm{OH})_{2} \mathrm{D}_{3}$ : To confirm the cancer suppression effect of $1,25(\mathrm{OH})_{2} \mathrm{D}_{3}$, the proliferation of the MCF7 cancer cells was monitored every 24 hours over 9 days utilizing fluorescence spectrometry under direct supply of $1,25(\mathrm{OH})_{2} \mathrm{D}_{3}$. MCF7 breast cancer cells were seeded in the standard 96-well microplate in a concentration of approximately 5,000 cells/well in triplicate. They were supplied with different dosing concentrations between $10^{-9}$ and $10^{-6} \mathrm{M}$ every 24 hours over 7 days. The cell viabilities were measured every 24 hours by the spectrometer. The optical images of the cells were also collected for comparison purposes.

By 25(OH)D $D_{3}$ : The cancer suppression effect of $25(\mathrm{OH}) \mathrm{D}_{3}$ on MCF7 breast cancer cells have been additionally examined by utilizing the identical method described above. In this case, different concentrations of $25(\mathrm{OH}) \mathrm{D}_{3}$ between $10^{-5}$ and $10^{-8} \mathrm{M}$ were applied. Note that to the best of our knowledge, cancer suppression effects of $25(\mathrm{OH}) \mathrm{D}_{3}$ on MCF breast cancer cells has not been reported previously. However, the hypothesis that mammary cells express CYP27B1 and locally produce $1 \alpha, 25(\mathrm{OH})_{2} \mathrm{D}_{3}$, which acts in an autocrine manner to regulate cell turnover had been studied previously [12]. CYP27B1 is a cytochrome P450-containing hydroxylase expressed in kidney and other tissues that generates $1 \alpha, 25(\mathrm{OH})_{2} \mathrm{D}_{3}$. In Bland et al.'s study, CYP27B1 mRNA was detected in both MCF7 and HKC8 cells lines, but expression was higher in MCF7 cultures compared with HKC8 cells [12], which were characterized previously as an in vitro model of vitamin D metabolism [9]. Thus we suspected that MCF7 cells may also convert $25(\mathrm{OH}) \mathrm{D}_{3}$ into $1,25(\mathrm{OH})_{2} \mathrm{D}_{3}$ by itself.

By indirectly produced $1,25(\mathrm{OH})_{2} \mathrm{D}_{3}$ : In comparison to direct applications of $25(\mathrm{OH}) \mathrm{D}_{3}$ and $1,25(\mathrm{OH})_{2} \mathrm{D}_{3}$ onto the cancer cells (MCF7), the application of $25(\mathrm{OH}) \mathrm{D}_{3}$ onto the kidney cells (HKC8) was examined. HKC8 cell has been known to produce $1,25(\mathrm{OH})_{2} \mathrm{D}_{3}$ from $25(\mathrm{OH}) \mathrm{D}_{3}[9]$. Thus, $\mathrm{HKC} 8$ cells were cultured at the upstream well, while MCF7 cells were cultured at the downstream well. In this case, HKC8 and MCF7 cells were separately cultured in the wells of a standard 96-well microplate. Every 24 hours, $25(\mathrm{OH}) \mathrm{D}_{3}$ was added to the HKC8 cells and after 5 hours of adding $25(\mathrm{OH}) \mathrm{D}_{3}$ to the HKC8 cells, the media in the HKC8 cell well was exchanged with fresh media without $25(\mathrm{OH}) \mathrm{D}_{3}$ while the "used" HKC8 media was exchanged with the media in the MCF7 cell well. The proliferation was measured every 24 hours over 9 days utilizing fluorescence spectrometry. The concentrations of the supplied $25(\mathrm{OH}) \mathrm{D}_{3}$ ranged between $10^{-5}$ and $10^{-7} \mathrm{M}$.

\section{Measurement of flow effects on cancer suppression}

In order to measure the flow rate effects on the cancer suppression, the proliferation of the MCF7 cancer cells in the in vitro platform were monitored using cellulose membranes with different pore sizes $(1.2,5.0$ or $8.0 \mu \mathrm{m})$ (Fig. 2). The average flow rates were previously measured as $1.3,3.3$, and $6.7 \mu 1 / \mathrm{hr}$ for the 
membrane pore sizes of $1.2,5.0$, and $8.0 \mu \mathrm{m}$, respectively [11]. In the first well HKC8 kidney cells were seeded, while MCF7 breast cancer cells were seeded in the second well (Fig.2). The initial cell numbers were approximately 5,000 cells/well. Depending on the induced flow rates (pore sizes of cellulose membranes), the applied media with or without $25(\mathrm{OH}) \mathrm{D}_{3}$ was adjusted in the first $\mathrm{HKC} 8$ cell well and the third drain well every 1, 2 or 3 days, respectively. After 5 days, the cell viabilities were measured by the same protocol as the previous tests.

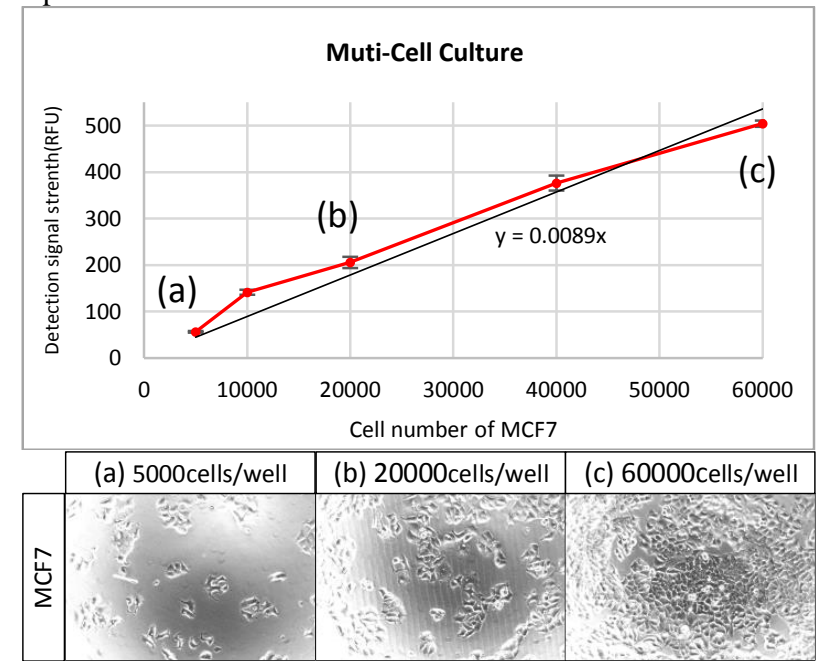

Figure 3: (Top) Measured reference curve from breast cancer (MCF7) cells. PrestoBlue in DMEM media

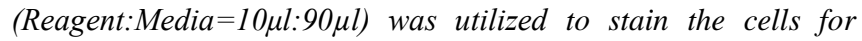
optical spectrometry for proliferation measurement (Synergy HT BioTEK with fluorescence 560/590nm). (Bottom) Photos of the cell growth

\section{RESULT}

\section{Cell viability: MCF7 breast cancer cells}

The fluorescence measurement showed that the relative fluorescence unit (RFU) monotonously increased from 56 to 504 with the increasing number of MCF7 cells from 5,000 to 60,000 cells/well (Fig. 3-(top)). A positive linear correlation was observed with a slope of $0.0089 \mathrm{RFU} /$ cells, indicating the validity of the curve as a cell growth reference. In the case of 5,000 cells/well, the surface of the well was covered with sparsely-distributed cells, while the well with 60,000 cells were nearly fully packed with the cells (Fig. 3-(bottom)).

\section{Breast cancer suppression by $1,25(\mathrm{OH})_{2} \mathrm{D}_{3}$}

The measurement results showed that $1,25(\mathrm{OH})_{2} \mathrm{D}_{3}$ with concentrations of $10^{-6} \mathrm{M}$ and $10^{-7} \mathrm{M}$ suppressed the proliferation of MCF7 cells by $36 \%$ in comparison to lower concentrations $\left(10^{-8} \mathrm{M}\right.$ and $\left.10^{-9} \mathrm{M}\right)$ and control $(0 \mathrm{M})$ on day 7 , as shown in Fig.4-(top). The suppression was clearly distinguished from day 4 , and the proliferation difference further increased with the time. The suppression differences were measured as $22,30,33 \%$ at day 4, 5, and 6 , respectively. The concentrations of $10^{-8} \mathrm{M}$ and $10^{-9} \mathrm{M}$ did not show any noticeable suppression in comparison to the control (0M). The optical images of $10^{-7} \mathrm{M}$ (suppression) and $10^{-9} \mathrm{M}$ (no suppression) present the clear differences in cancer cell proliferation (Fig.4-(bottom)). After day 7, MCF7 cells in the control and $10^{-8}$, $10^{-9} \mathrm{M}$ wells, started peeling off from the wall due to extremely high cell density from cell growth.

Breast cancer suppression by $25(\mathrm{OH}) \mathrm{D}_{3}$

The suppression data indicated that concentrations of $25(\mathrm{OH}) \mathrm{D}_{3}$ above $10^{-6} \mathrm{M}$ were capable of suppressing the proliferation of MCF7 cells by $54 \%$ on day 7, while the lower concentrations $\left(10^{-7} \mathrm{M}\right.$ and $\left.10^{-8} \mathrm{M}\right)$ showed little suppression, as shown in Fig.5-(top). To the best of our knowledge, this is the first experimental results that showed the cancer cell suppression by $25(\mathrm{OH}) \mathrm{D}_{3}$. The cancer suppression effects become distinct from day 4 , and the proliferation difference further increased with time. The suppression differences were measured as $32,44,46 \%$ at day 4,5 , and 6 , respectively. The optical images of $10^{-5} \mathrm{M}$ (suppression) and $10^{-8} \mathrm{M}$ (little suppression) presented the clear differences in cancer cell proliferation (Fig.5-(bottom)).
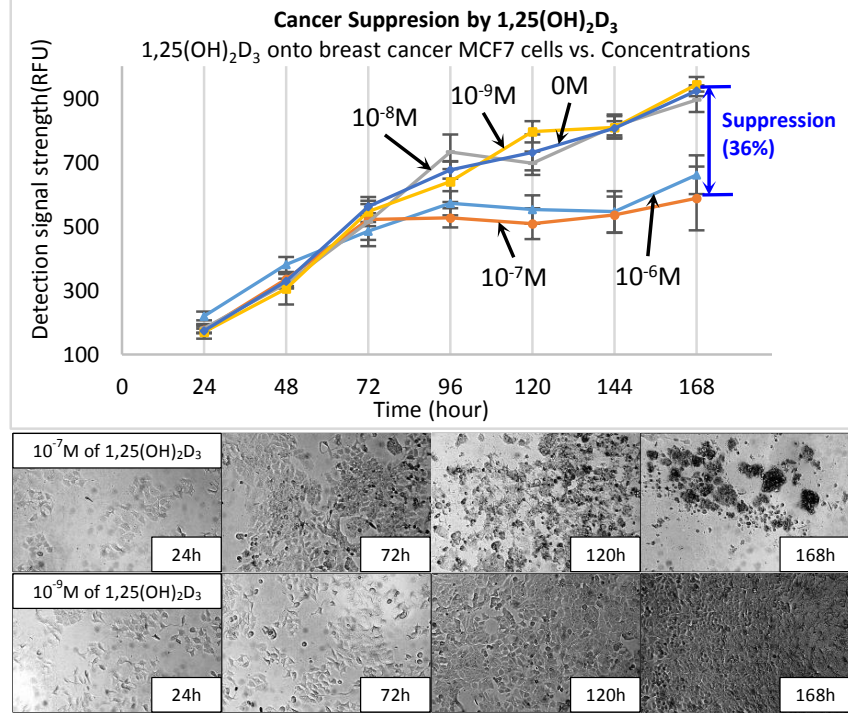

Figure 4: (Top) Measured MCF7 suppression in fluorescence intensities over time under different dosing concentrations by $1,25(\mathrm{OH})_{2} \mathrm{D}_{3}$, indicating the effects of concentrations. (Bottom) Photos of breast cancer cells showing the suppression effects at higher concentrations of $>10^{-7} \mathrm{M}$.
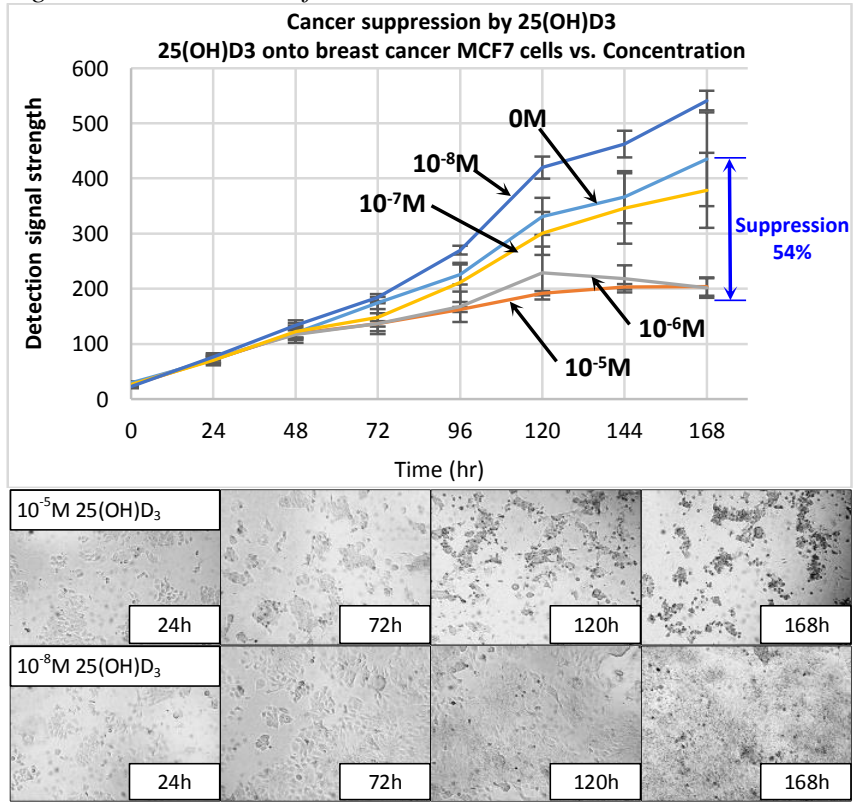

Figure 5: (Top) Measured MCF7 suppression in fluorescence intensities over time under different dosing concentrations by $25(\mathrm{OH}) D_{3}$. (Bottom) Photos of breast cancer cell suppression over time, demonstrating the effects of dosing concentrations $\left(>10^{-8} \mathrm{M}\right)$.

Breast cancer suppression by converted $1,25(\mathrm{OH})_{2} \mathrm{D}_{3}$

The normalized cell proliferation data showed that MCF7 
cancer cells, located at the downstream, were suppressed under the application of $25(\mathrm{OH}) \mathrm{D}_{3}$ onto the HKC8 kidney cells upstream. The suppression was up to $48 \%$ in comparison to the control (0M) samples after 7 days (Fig. 6-(top)), which was close to the results from the direct application of $25(\mathrm{OH}) \mathrm{D}_{3}$ onto the MCF7 breast cancer cells (Fig. 5-(top)). Although this small difference $(48 \%$ compared with 54\%) was within our experimental error, more experiments are needed in order to isolate the path of MCF7 suppression to whether $25(\mathrm{OH}) \mathrm{D}_{3}$ was indeed converted into $1,25(\mathrm{OH}) \mathrm{D}_{3}$ by the HKC8 kidney and/or MCF7 cells. Further study is needed to explain the exact causes.

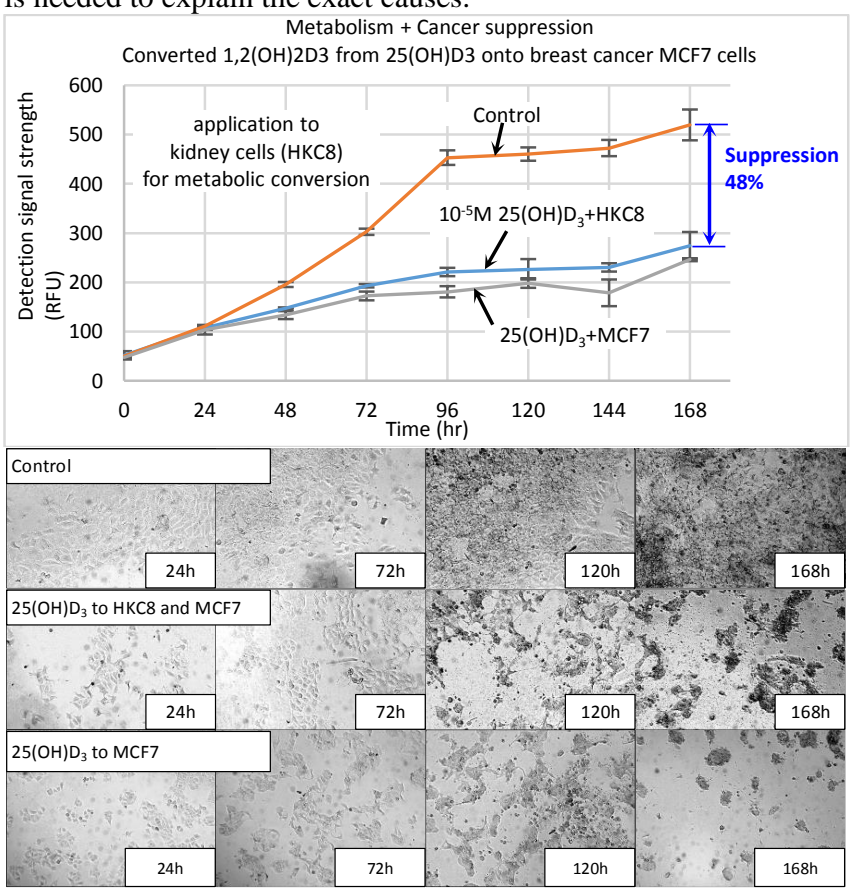

Figure 6: (Top) Measured MCF7 suppression in fluorescence intensities over time under different dosing conditions of 25(OH)D : (top) control, (middle) onto HKC8 kidney cells, and (bottom) onto MCF7 cells. (Bottom) Photos of breast cancer cell suppression over time.

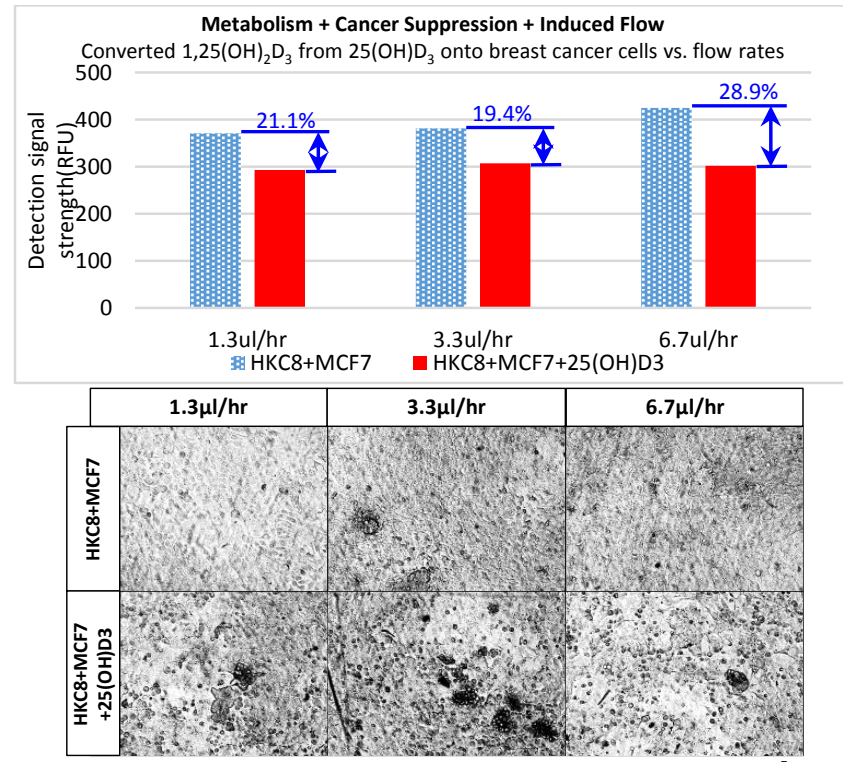

Figure 7: (Top) Measured MCF7 suppression with $10^{-5} \mathrm{M}$ of $25(\mathrm{OH}) \mathrm{D}_{3}$ added to the HKC8 cell wells upstream by measuring the fluorescence intensities in the induced flow in vitro model after 5 days culture. (Bottom) Photos of cell suppression under different flow rates of $1.3,3.3$, and $6.7 \mathrm{ul} / \mathrm{hr}$.

\section{Breast cancer suppression at different flow rates}

The measurement data demonstrated that different flow rates of $1.3,3.3$ and $6.7 \mathrm{ul} / \mathrm{hr}$ resulted in different levels of cancer cell suppression of $21.1,19.4$ and $28.9 \%$ with $10^{-5} \mathrm{M}$ of $25(\mathrm{OH}) \mathrm{D}_{3}$ added to the HKC8 cell well, as illustrated in Fig.7-(top). The maximum suppression of $28.9 \%$ was observed at the highest flow rate of $6.7 \mathrm{ul} / \mathrm{hr}$. We are still trying to understand the relatively lower suppression compared with previous cases (Fig. 4-6-(top)). The optical images also supported the trend: different levels of MCF7 suppression under different flow rates.

\section{DISCUSSIONS AND CONCLUSIONS}

This paper presents an in vitro platform that simultaneously enables (1) co-culture of multiple cells in one system; (2) induced fluidic flows by different pressure; (3) cancer suppression by the derivatives of vitamin $\mathrm{D}_{3}$. The cancer suppression distinctly appeared at the concentrations of $1,25(\mathrm{OH})_{2} \mathrm{D}_{3}$ above $10^{-7} \mathrm{M}$ after 96 and 72 hours for each cases and of $25(\mathrm{OH}) \mathrm{D}_{3}$ above $10^{-6} \mathrm{M}$ after 96 hours, while the suppression differences, in comparison to control (0M), were measured as $36 \%, 54 \%$ and $48 \%$, respectively. The measurement data also showed that the cancer suppression reaches $28.9,21.1,19.4 \%$ with $10^{-5} \mathrm{M}$ of $25(\mathrm{OH}) \mathrm{D}_{3}$ at the flow rates of 6.7 , 1.3 and $3.3 \mu \mathrm{l} / \mathrm{hr}$, respectively.

\section{ACKNOWLEDGEMENTS}

Fabrication was performed at the state-of-the-art University of Utah Nano Fabrication Facility located in the Sorenson Molecular Biotechnology Building. The authors thank Prof. Hamid Ghandehari's group (University of Utah, Salt Lake City, UT) for the access of HPLC instrument, advice and support. HKC8 human renal proximal tubule cell lines and MCF7 breast cancer cell lines were kindly provided by Dr. Anthony A. Portale (University of California, San Francisco, CA) and by Dr. Alana Welm (University of Utah, Salt Lake City, UT), respectively. The 96-well perfusion microplate was generously provided by Corning Incorporated (Corning, NY).

\section{REFERENCES}

[1] National Institutes of Health, Fact Sheet, Oct, 2011.

[2] Bernard Fisher et al., Journal of the National Cancer Institute, 1998, 90, pp.1371-88

[3] Clarke M, et al., the Lancet, 2005, 366, pp.2087-2106

[4] Charles L. Shapiro, et al., The New England Journal of Medicine, 2001, 344, pp.1997-2008

[5] Early Breast Cancer Trialists' Collaborative Group, Lancet, 2005, 365, pp.1687-1717

[6] Simon Skjode Jensen, et al., Molecular Endocrinology, 2001, 15, pp. $1370-1380$

[7] Axmin Zittermann, British Journal of Nutrition, 2003, 89, pp.552-572

[8] Daniel Zehnder, et al., Journal of Clinical Endocrinology, 2001, 86, pp.888-894

[9] Rosemary Bland, et al., Endocrinology, 1999, 140, pp.20272034

[10] Ross Booth, et al., Lab on a Chip, 2012, 12, pp1784-1792

[11] Vasiliy N. Goral, et al., Lab on a Chip, 2013, 13, pp.1039-1043

[12] Carly M. Kemmis, et al., The Journal of Nutrition, 2006, 136, pp.887-892

\section{CONTACT}

*Seungbeom Noh, tel: +1-801-585-4766; moses.noh@utah.edu 